\title{
Comparative study on the water quality status of Andra reservoir and Denkada anicut constructed on Champavati River, Vizianagaram, India
}

\author{
G V. S. R. Pavan Kumar ${ }^{1}$ K. Rama Krishna ${ }^{2}$
}

Received: 9 February 2015/Accepted: 25 August 2015/Published online: 18 September 2015

(C) The Author(s) 2015. This article is published with open access at Springerlink.com

\begin{abstract}
The author's present study was carried out for a period of 3 years from 2010 to 2013 to itemize the various physico-chemical parameters, irrigation water quality parameters and heavy metals in Champavathi River waters at Andra reservoir and Denkada anicut. Water samples were collected from the chosen sampling stations of the two reservoirs for every 4 months and analyzed as per APHA standard methods. The results obtained were compared with IS 10500 standards and found to be well within the prescribed values. Though the obtained values were well within the prescribed standard values, it was found that the water quality index, concentration of certain parameters such as calcium, magnesium, sodium and potassium of the waters of Andra reservoir are higher than that of the Denkada anicut, and the concentration of nitrite was found to be higher in the water sample analyzed from Denkada anicut. Except silicon, all the other metals were found to be below the detection limits in the two reservoir waters. The reasons for the same were probed by the authors in the presented study. From the analysis reports, it was found that the water analyzed from the two reservoirs was fit for irrigation, agriculture, industrial and domestic purposes.
\end{abstract}

G V. S. R. Pavan Kumar

prs.ganti@gmail.com

K. Rama Krishna

rk.karipeddi@yahoo.co.in

1 Department of Chemistry, M V G R College Of Engineering, Vizianagaram, India

2 Department of Chemistry, GITAM Institute of Sciences, GITAM University, Visakhapatnam, India
Keywords Water quality index $\cdot$ Physico-chemical characterization - Andra reservoir - Denkada anicut . Vizianagaram · Irrigation projects

\section{Introduction}

The hydrochemical study of quality of water reveals that it is suitable for drinking, agriculture, industrial and irrigation purposes (Nagaraju et al. 2014). The availability of good quality water is an indispensible feature for preventing diseases and improving the quality of life (Nabila et al. 2014). The healthy aquatic ecosystem is dependent on physico-chemical and biological characteristics (Tirupathaiah et al. 2012). The analysis of freshwater is an important and sensitive issue in water quality monitoring. Its main objective is to control and reduce the incidence of pollutant-related problems (Akoto and Abankua 2014). Water, the matrix of life, is exposed to pollution, unhealthy environment resulting in human affliction and diseases, the reason being rapid industrialization and increase in population (John Mohammad et al. 2015). Water quality monitoring of aquatic systems like reservoir serves as a tool for planning and management of the river basin. The impact of human activities directly influences the lake habitat and can alter the environment of the lake or reservoir (Pavan Kumar et al. 2013). To make the entire ayacut fertile and for feasible distribution of the available water of the river to irrigation and agricultural purposes, reservoirs are constructed. It is important to know the quality of water at each of such reservoirs constructed across the same river to assess whether the water is fit for human consumption for different purposes. In the present study, the author attempted to compare the physical and chemical parameters, irrigation water quality, 
heavy metals and water quality data of two selected reservoirs, namely Andra and Denkada anicut constructed on the River Champavathi.

River Champavathi originates in the Eastern Ghats of south India at an altitude of $1200 \mathrm{~m}$ above MSL near Andra village, flows eastward and joins the Bay of Bengal at Konada village. The basin has a drainage area of $1410 \mathrm{~km}^{2}$. For the purpose of irrigation and agriculture, two reservoirs are constructed on the river, one at the originating place, Andra reservoir, and the other, Denkada anicut, which is $30 \mathrm{~km}$ away from the estuarine point of the river. Andra reservoir (Fig. 21) is located in Andra village near the originating place of the river, at $18.3500^{\circ} \mathrm{N}$ $83.2000^{\circ} \mathrm{E}$. It has an average elevation of $127 \mathrm{~m}$ (419 feet). The project utilizes $0.980 \mathrm{TMC}$ of the available water and the reservoir storage capacity is about $0.9 \mathrm{TMC}$. The total ayacut of 9426 acres has been stabilized in Bondapalli,
Gajapathinagaram and Mentada Mandals of Vizianagaram districts of Andhra Pradesh, India. The Denkada aniuct (Fig. 21) was also constructed across Champavathi River near the estuarine point of the river. The project is located near Saripalli Village, Nellimarla Mandal, Vizianagaram District for irrigation of a total ayacut of 5,153 acres in the district. The project utilizes $0.640 \mathrm{TMC}$ of the available water. The Denakda anicut is situated at $18^{\circ} 7^{\prime} 51^{\prime \prime} \mathrm{N}$ $83^{\circ} 28^{\prime} 36^{\prime \prime} \mathrm{E}$. These two reservoirs were constructed for the purpose of irrigation and hence it is necessary to assess the quality of the waters of the two reservoirs. The distance between the two reservoirs is $50 \mathrm{~km}$. Ten semi-urban towns are situated throughout the flow of the river in between. Pollution due to agricultural waste, manmade acts and disposal of animal waste into the river are observed in the lower catchment of the Andra reservoir to Denkada anicut. Hence, a comparative study is presented

Table 1 A comparative report on physico-chemical parameters

\begin{tabular}{|c|c|c|c|c|c|c|c|c|c|c|c|c|c|c|}
\hline \multirow[t]{2}{*}{ Season } & \multicolumn{2}{|c|}{ Chloride } & \multicolumn{2}{|c|}{ Phosphate } & \multicolumn{2}{|c|}{ Nitrite } & \multicolumn{2}{|c|}{ Fluoride } & \multicolumn{2}{|l|}{ TA } & \multicolumn{2}{|c|}{ Carbonate } & \multicolumn{2}{|c|}{ Bicarbonate } \\
\hline & A & D & A & $\mathrm{D}$ & A & D & A & D & A & $\mathrm{D}$ & A & $\mathrm{D}$ & A & D \\
\hline S1 & 98.5 & 135 & 0.5 & 0.1 & 0.05 & 0.3 & 0.1 & 0.2 & 159.5 & 206 & 18.1 & 18.5 & 111 & 185 \\
\hline $\mathrm{S} 2$ & 86.2 & 51.2 & 0.8 & 0.2 & 0.03 & 0.2 & 0.4 & 0.1 & 159.5 & 200 & 18.1 & 18.5 & 111 & 185 \\
\hline S3 & 95 & 51.8 & 1 & 0.3 & 0.03 & 0.2 & 0.4 & 0.1 & 160.5 & 199 & 36.1 & 35.2 & 222 & 193 \\
\hline S4 & 100 & 55 & 0.8 & 0.3 & 0.03 & 0.2 & 0.4 & 0.1 & 150.8 & 195 & 38.2 & 35.2 & 225 & 190 \\
\hline S5 & 100 & 58 & 0.9 & 0.3 & 0.03 & 0.1 & 0.5 & 0.1 & 165 & 199 & 40 & 37 & 228 & 195 \\
\hline S6 & 98 & 52.5 & 1.2 & 0.3 & 0.03 & 0.2 & 0.6 & 0.1 & 160 & 201 & 38.5 & 37 & 235 & 195 \\
\hline S7 & 98 & 52 & 1.2 & 0.3 & 0.03 & 0.2 & 0.6 & 0.1 & 165 & 200 & 38.5 & 41 & 235 & 200 \\
\hline S8 & 95.5 & 52.5 & 1.1 & 0.3 & 0.03 & 0.2 & 0.7 & 0.1 & 168 & 198 & 38.5 & 39.5 & 229 & 199 \\
\hline S9 & 98.2 & 52 & 1.1 & 0.3 & 0.03 & 0.2 & 0.9 & 0.1 & 165 & 200 & 40 & 39.5 & 229 & 199 \\
\hline S10 & 100 & 52 & 1 & 0.3 & 0.05 & 0.2 & 0.8 & 0.1 & 165 & 206 & 42 & 40 & 231 & 198 \\
\hline S11 & 150 & 55 & 1.2 & 0.5 & 0.06 & 0.1 & 0.8 & 0.3 & 170 & 200 & 45 & 39 & 230 & 190 \\
\hline
\end{tabular}

EC is expressed in $\mu \mathrm{S} / \mathrm{cm}$ and all others are expressed in $\mathrm{mg} / \mathrm{L}$

Table 2 WQI and irrigation water quality parameters: a comparative analysis report

\begin{tabular}{|c|c|c|c|c|c|c|c|c|c|c|}
\hline \multirow{2}{*}{$\frac{\text { S.No }}{\mathrm{S} 1}$} & \multicolumn{2}{|l|}{ SAR } & \multicolumn{2}{|l|}{ RSC } & \multicolumn{2}{|l|}{$\% \mathrm{Na}$} & \multicolumn{2}{|c|}{ Mg hazard } & \multicolumn{2}{|l|}{ WQI } \\
\hline & 1.537 & 1.31 & -5 & -3.8 & 27.9 & 24.3 & 46.4 & 46.4 & 24.9 & 39.6 \\
\hline $\mathrm{S} 2$ & 1.308 & 1.3 & -1.5 & -0.3 & 31.3 & 30.8 & 49.5 & 49.6 & 23.5 & 31.8 \\
\hline $\mathrm{S} 3$ & 0.376 & 0.79 & -1.2 & -1.07 & 9.71 & 18.9 & 32.9 & 49.2 & 36.4 & 32.4 \\
\hline S4 & 1.374 & 0.9 & -0.03 & -1.41 & 29.25 & 20.6 & 39.8 & 47.4 & 29.1 & 32.4 \\
\hline S5 & 1.132 & 0.97 & -2.9 & -1.63 & 27.75 & 21.3 & 37.2 & 45.7 & 32.1 & 26.9 \\
\hline S6 & 1.922 & 0.95 & -3.5 & -1.86 & 30.1 & 20.8 & 36.45 & 45.5 & 35.1 & 32.5 \\
\hline S7 & 1.922 & 0.87 & -3.5 & -1.4 & 30.1 & 19.5 & 36.45 & 46.8 & 35.1 & 32.4 \\
\hline S8 & 1.827 & 0.9 & -2.9 & -1.1 & 30 & 20.5 & 37.43 & 47.4 & 35.6 & 32.4 \\
\hline S9 & 1.759 & 0.92 & -3.5 & -1.8 & 28.5 & 19.9 & 28.6 & 49.5 & 38.5 & 32.5 \\
\hline S10 & 1.841 & 0.97 & -3.8 & -1.12 & 36.15 & 20.9 & 36.31 & 47.4 & 38.7 & 32.4 \\
\hline S11 & 1.93 & 1.15 & -4.41 & -1.29 & 29.2 & 25.1 & 25.1 & 38.1 & 36.4 & 30.2 \\
\hline
\end{tabular}


in this article on the seasonal variation in the physicochemical parameters, water quality index and heavy metal analysis.

In literature, comparative studies on the reservoir water quality was taken up all over the world (Chwowdary et al. 2011; Janeshwar et al. 2012; Swaranlatha and Narsingrao 1998; Pandey et al. 1993; Bhadja et al. 2013; Vaghela 2013). In light of this, the author presented a comparative study on the water quality of the two reservoirs on the River Champavathi.

\section{Materials and methods}

The samples were collected during different seasons of August 2010 (S1), December 2010 (S2), April 2011 (S3), August 2011 (S4), December 2011 (S5), April 2012 (S6), August 2012 (S7), December 2012 (S8) April 2013 (S9), August 2013 (S10) and December 2013 (S11). The samples were collected in previously cleaned polyethylene bottle of capacity $1000 \mathrm{ml}$ and mixed with appropriate preservatives for further analysis. EC, temperature, $\mathrm{pH}$ and $\mathrm{DO}$ of the

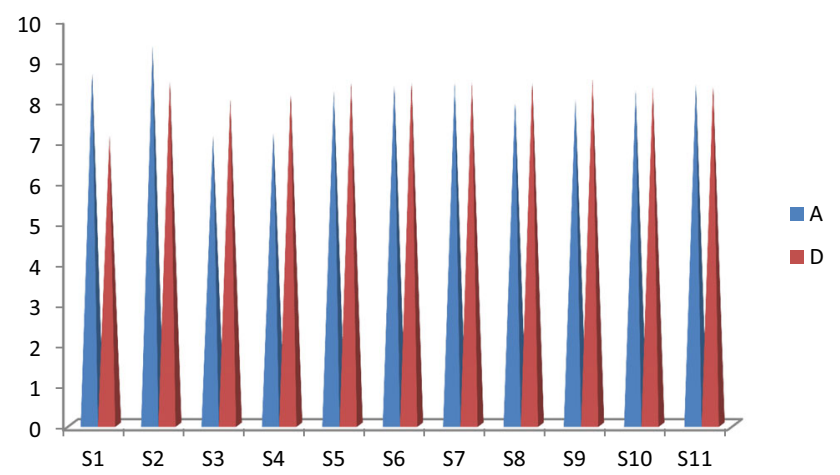

Fig. 1 Seasonal variation in $\mathrm{pH}$ for the two reservoir waters-a comparative representation

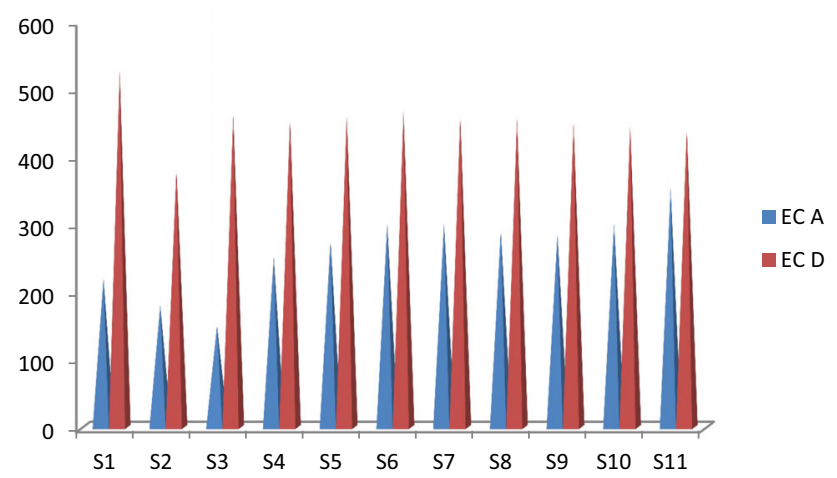

Fig. 2 Seasonal variation in EC for the two reservoir waters-a comparative representation collected samples were measured on the spot. The concentration of chloride ion in the water sample was determined by Mohr's method using potassium chromate as an indicator. Concentrations of calcium and magnesium were determined by using EDTA with EBT and murexide indicators. All these analyses were performed based on the APHA methods (Clesceri 1993).

\section{Results and discussion}

The complete comparative data on the physico-chemical parameters is presented in Table 1, and irrigation water quality parameters and WQI are presented in Table 2. Comparative seasonal variations in the physico-chemical characters, irrigation water quality parameters and water quality index data are presented in Figs. 1, 2, 3, 4, 5, 6, 7, $8,9,10,11,12,13,14,15,16,17,18,19$ and 20 . A comparison of the results obtained with IS 10500 standards and WHO standards was also done and found that all the values obtained were found to be well within the prescribed standard values (IS 10500, BIS 1991) (WHO 1993).

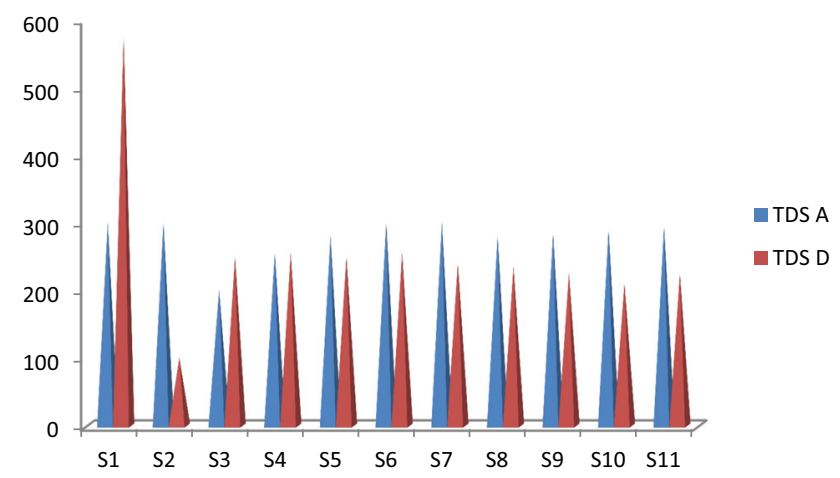

Fig. 3 Seasonal variation in TDS for the two reservoir waters-a comparative representation

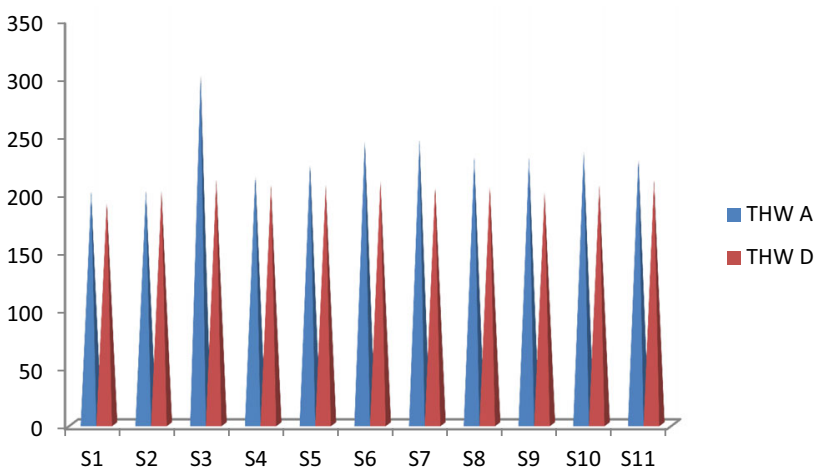

Fig. 4 Seasonal variation in THW for the two reservoir waters-a comparative representation

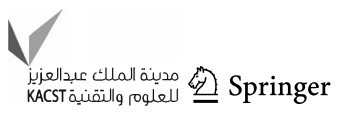




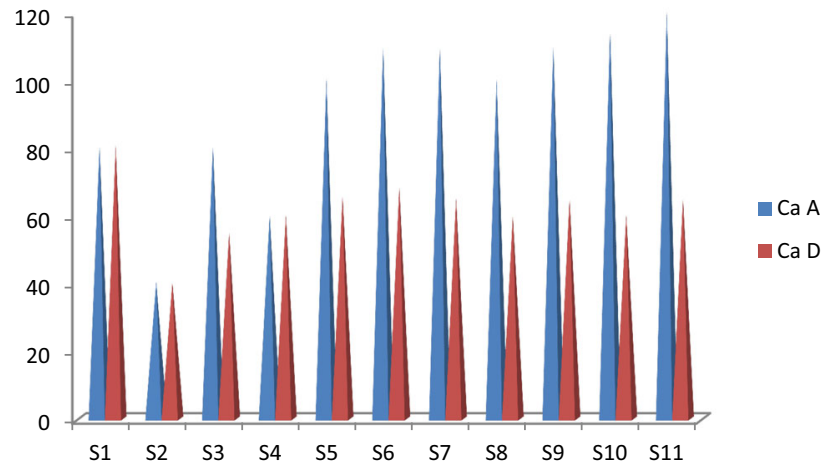

Fig. 5 Seasonal variation in calcium for the two reservoir waters-a comparative representation

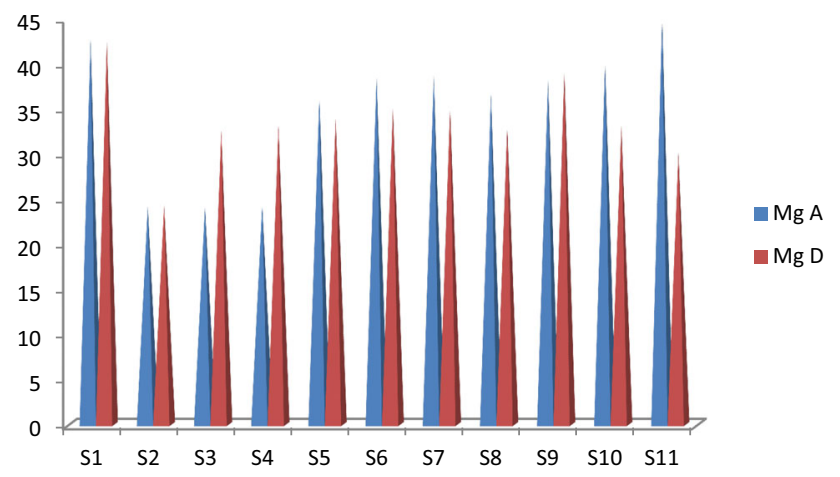

Fig. 6 Seasonal variation in magnesium for the two reservoir waters-a comparative representation

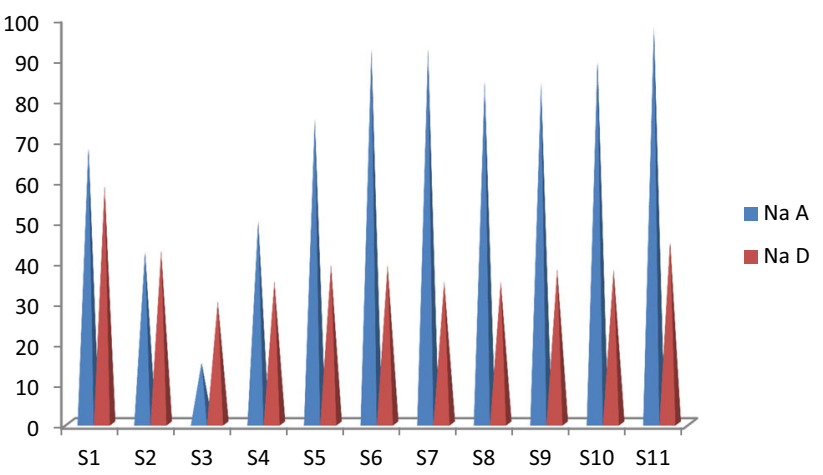

Fig. 7 Seasonal variation in sodium for the two reservoir waters-a comparative representation

The $\mathrm{pH}$ values of the water samples analyzed from the two reservoirs were found to be well within the prescribed standard values. The highest $\mathrm{pH}$ of 9.3 was observed for the water from the Andra reservoir during December 2010. From the data, it was concluded that the water was slightly alkaline in both the reservoirs and no appreciable variation was found between them.

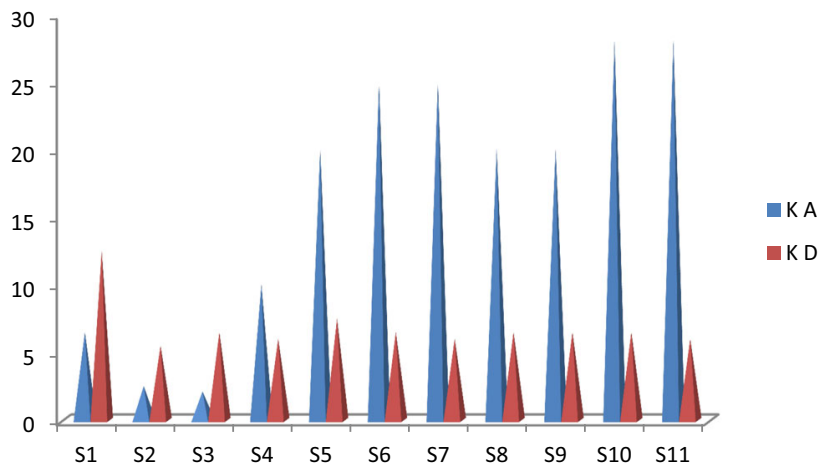

Fig. 8 Seasonal variation in potassium for the two reservoir watersa comparative representation

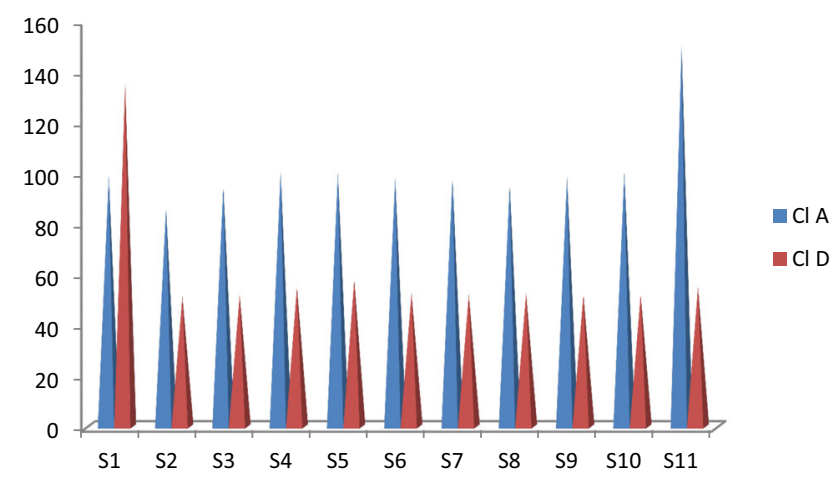

Fig. 9 Seasonal variation in chloride for the two reservoir waters-a comparative representation

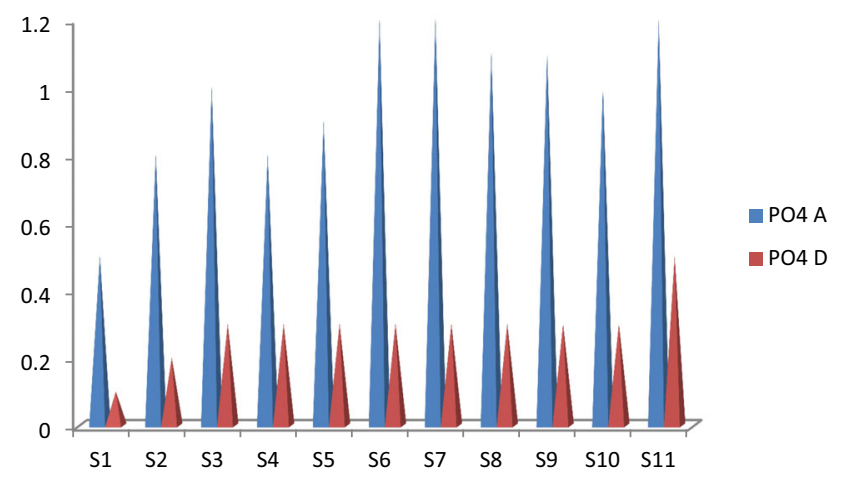

Fig. 10 Seasonal variation in phosphate for the two reservoir waters-a comparative representation

From the data of electrical conductivity, it was observed that the EC values for the two reservoirs were well within the standard values prescribed for both drinking and irrigation purposes. Though the values of EC were well within the standards stipulated, on comparison slightly higher values of EC were observed for the water samples collected and analyzed from Andra reservoir. The reservoir is constructed 


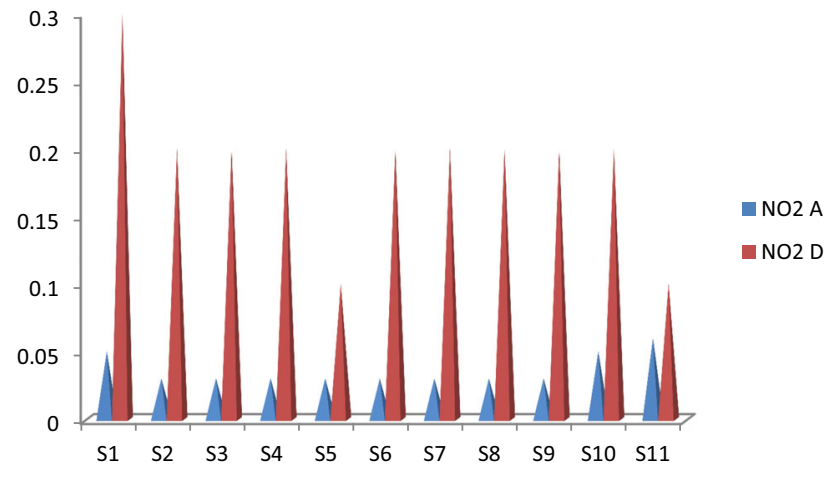

Fig. 11 Seasonal variation in nitrite for the two reservoir waters-a comparative representation

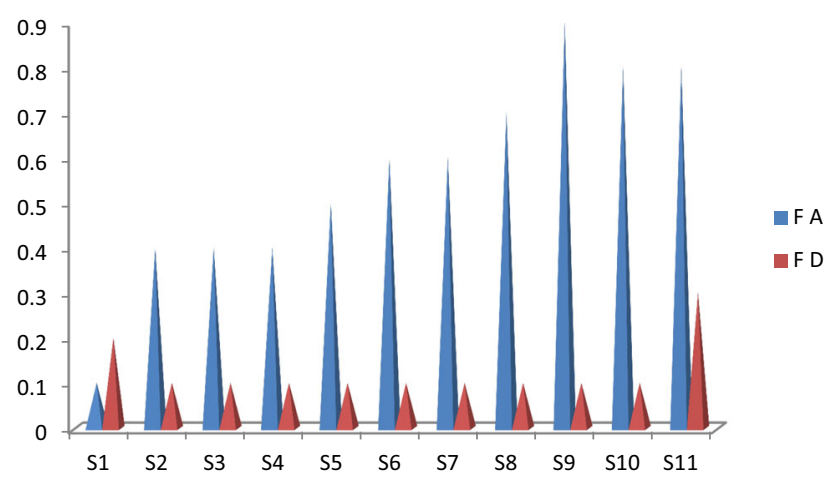

Fig. 12 Seasonal variation in fluoride for the two reservoir waters-a comparative representation

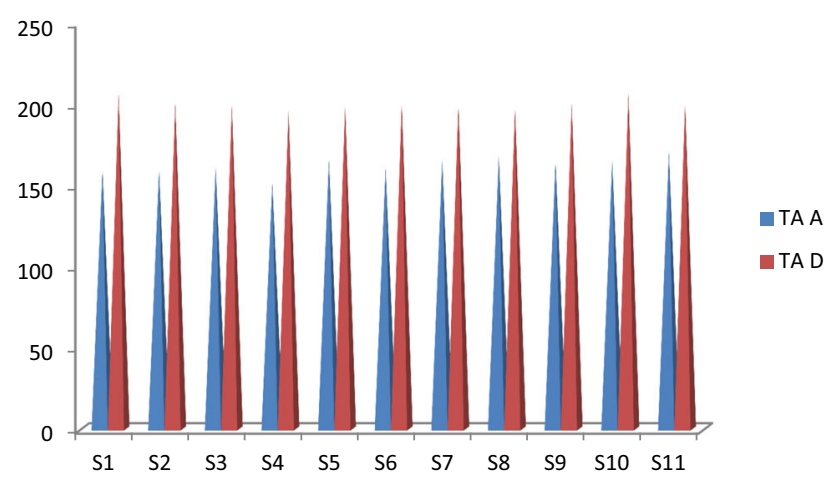

Fig. 13 Seasonal variation in TA for the two reservoir waters-a comparative representation

close to the origin of the river, water of the reservoir is found not to be influenced by the various physical and chemical pollution or natural or manmade acts.

The concentration levels of total hardness of water, calcium and magnesium were found to be well within the prescribed standard limit values. In all the seasons under study, no variation in the concentration levels of the

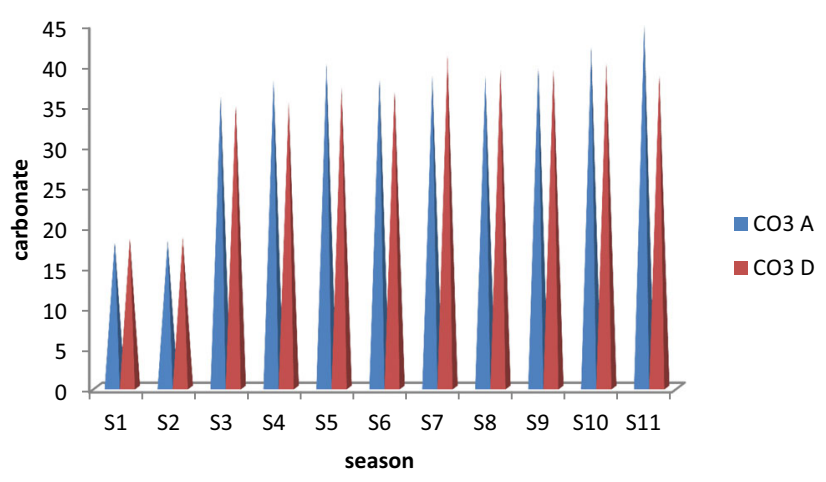

Fig. 14 Seasonal variation in carbonate for the two reservoir waters - a comparative representation

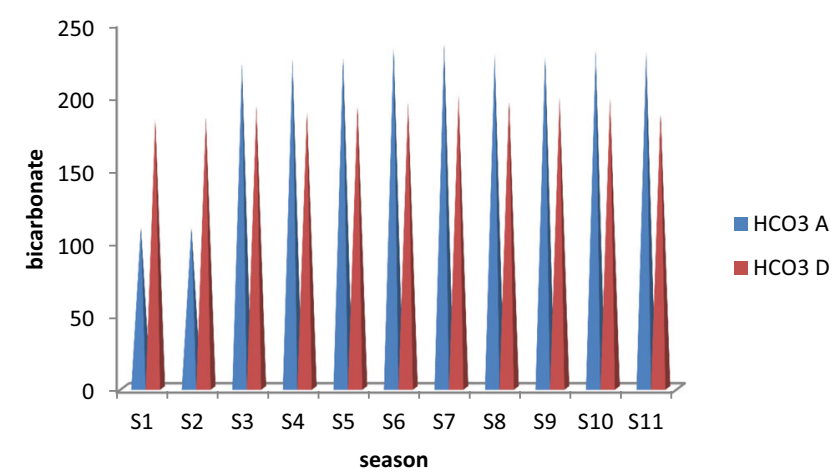

Fig. 15 Seasonal variation in bicarbonate for the two reservoir waters - a comparative representation

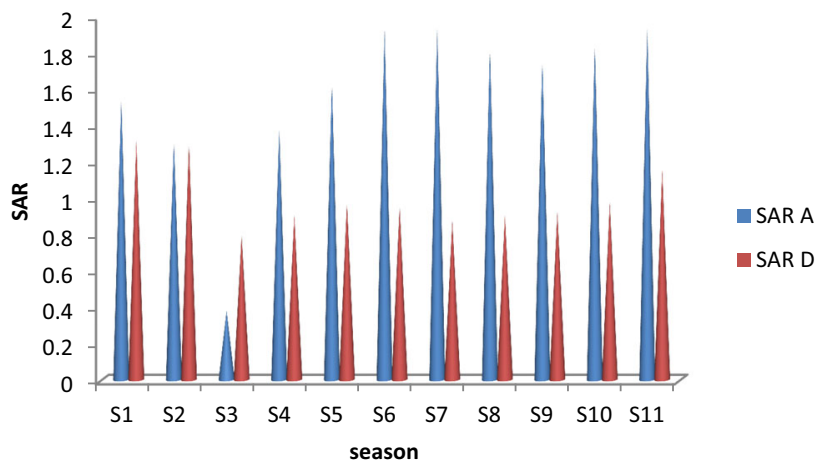

Fig. 16 Seasonal variation in SAR for the two reservoir waters-a comparative representation

parameters mentioned was found in the two reservoirs. Sodium, potassium, chloride, fluoride and phosphate were found to be higher in the water analyzed from the Andra reservoir than the Denkada anicut. Though there was variation in the concentration of the parameters between both the reservoirs, all the results obtained were well within the prescribed standard values. The reasons for the 


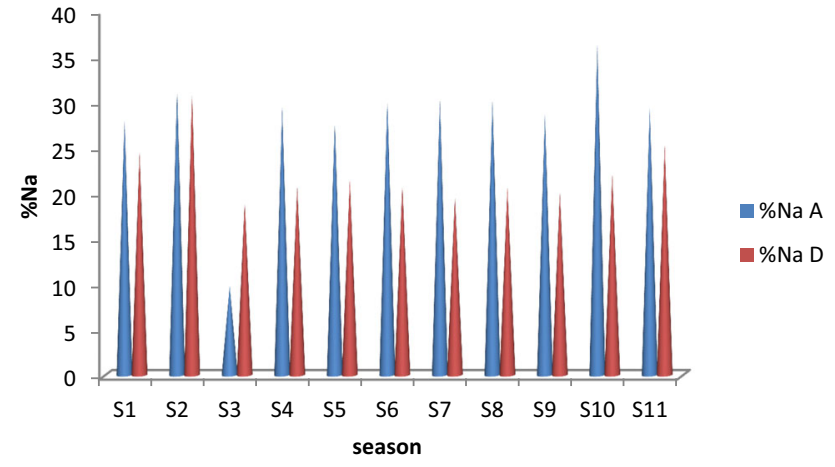

Fig. 17 Seasonal variation in $\% \mathrm{Na}$ for the two reservoir waters-a comparative representation

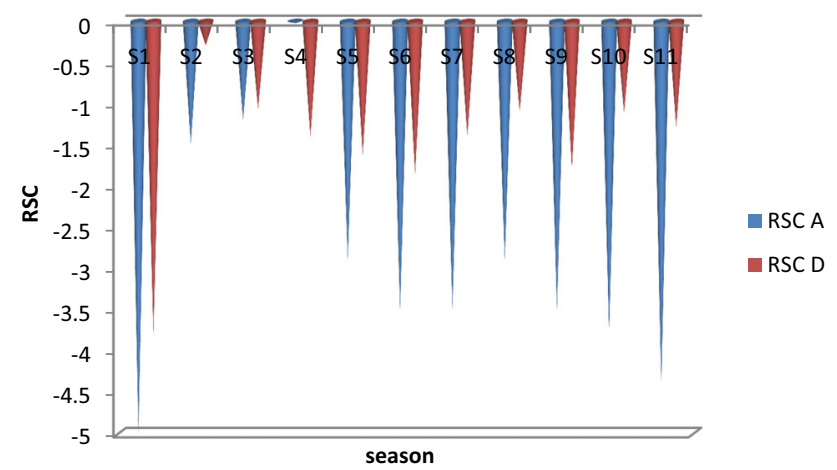

Fig. 18 Seasonal variation in RSC for the two reservoir waters-a comparative representation

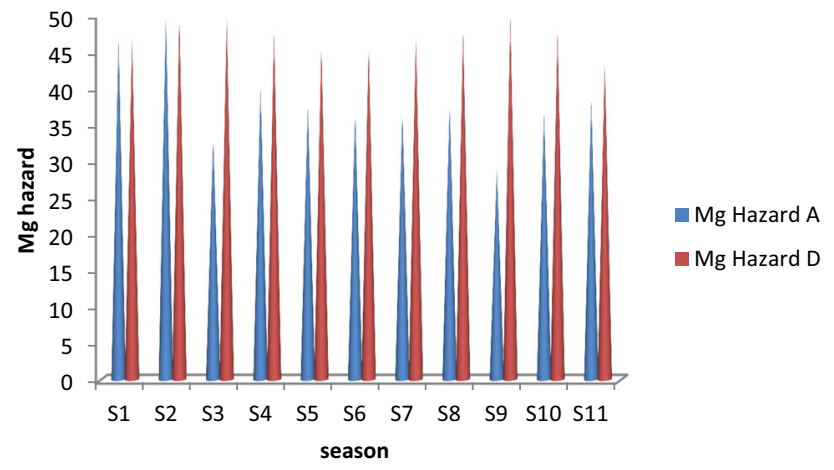

Fig. 19 Seasonal variation in Mg-hazard for the two reservoir waters-a comparative representation

variation in the concentration of different parameters mentioned above are as follows:

(a) It was observed that the Andra reservoir was constructed at the origin of the river. In such conditions, the water of the river is away from the influence of the soil and conditions through which it flows.

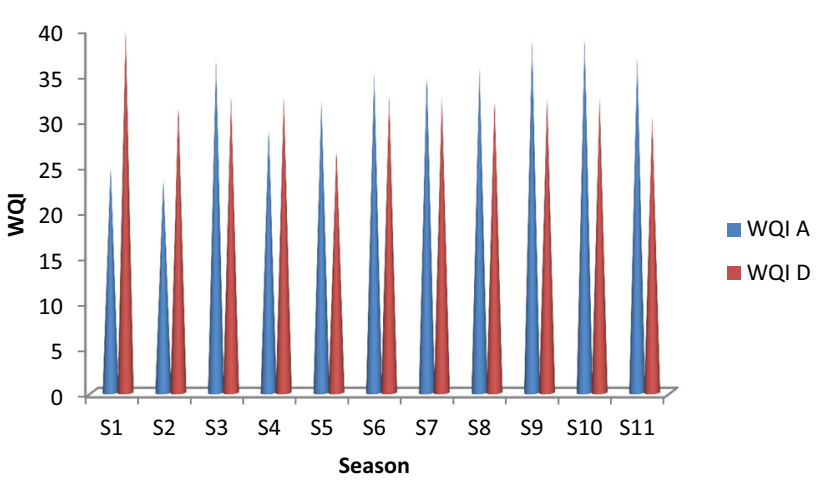

Fig. 20 Seasonal variation in WQI for the two reservoir waters-a comparative representation

(b) As the river flows from the reservoir downstream, during its travel, it comes in contact with a variety of conditionings such as soil (Ray Chaudhary 1941) and contamination with pollutants. It was observed that most of the soils in the district of Vizianagaram were red soils, sandy loams and sandy clay. These soils are porous textured and leaching dominant. As the river flows through this soil, the chemical constituents present in the water may be sedimented and makes the water with lower concentrations of the aforesaid parameters and hence the trend of high levels of the parameters was found in the reservoir at the originating place and lower concentration the same at the other, Denkada anicut.

(c) In most of the seasons under investigation, fluoride ion concentration was found to be lower in the water samples of Denkada anicut to that of Andra reservoir. This indicates that the waters of the Denkada anicut are not contaminated with agricultural runoff (Sharma et al. 2013).

(d) During August 2010, a higher value of TDS was found in the water samples of Denkada anicut. This is due to the dissolution of salts into the water of the reservoir. In all the other seasons, the value of TDS was found to be below the value reported in the seasons mentioned above.

It was found that the concentration of nitrite in the waters of the Denkada anicut was higher than that of Andra reservoir. Nitrite enters water bodies from municipal and industrial wastewater, septic tanks, feed lot discharges, animal wastes (including birds and fish), runoff from fertilized agricultural field and lawns and discharges from automobile exhausts. It was observed that animal waste is fed into the river at a place near the Denkada anicut, which is the reason for the high levels of nitrite in the anicut waters. Wastes and seepage fed into the river under study is presented in Figs. 21, 22 and 23. Though higher levels of nitrite is observed in the Denkada anicut compared to that 
Fig. 21 Household seepage fed into Champavathi River

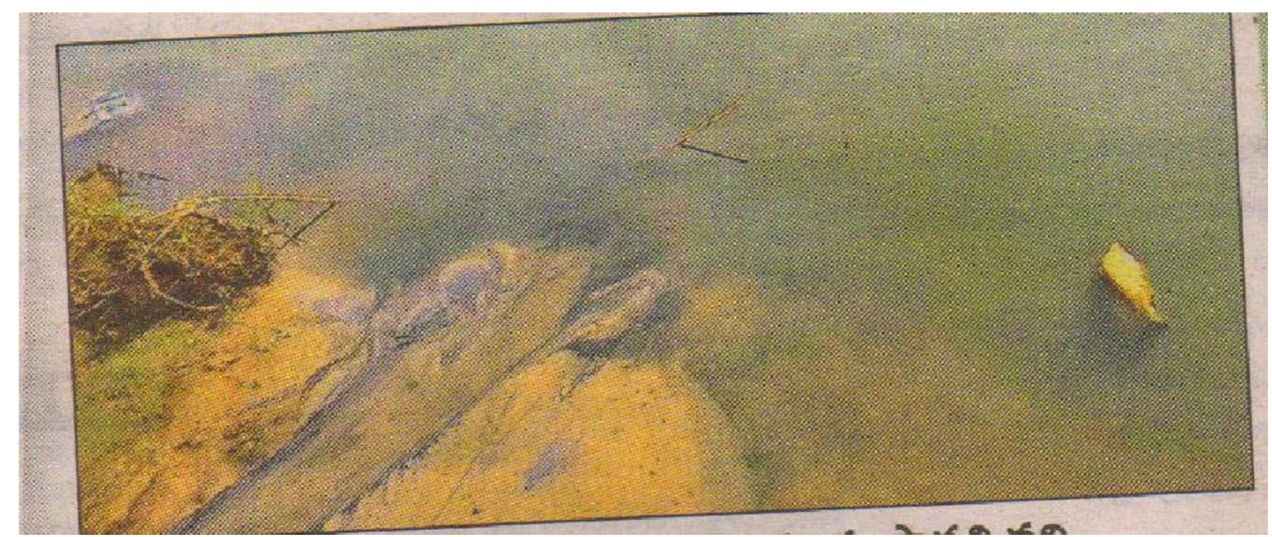

Fig. 22 Solid waste from houses into Champavathi River

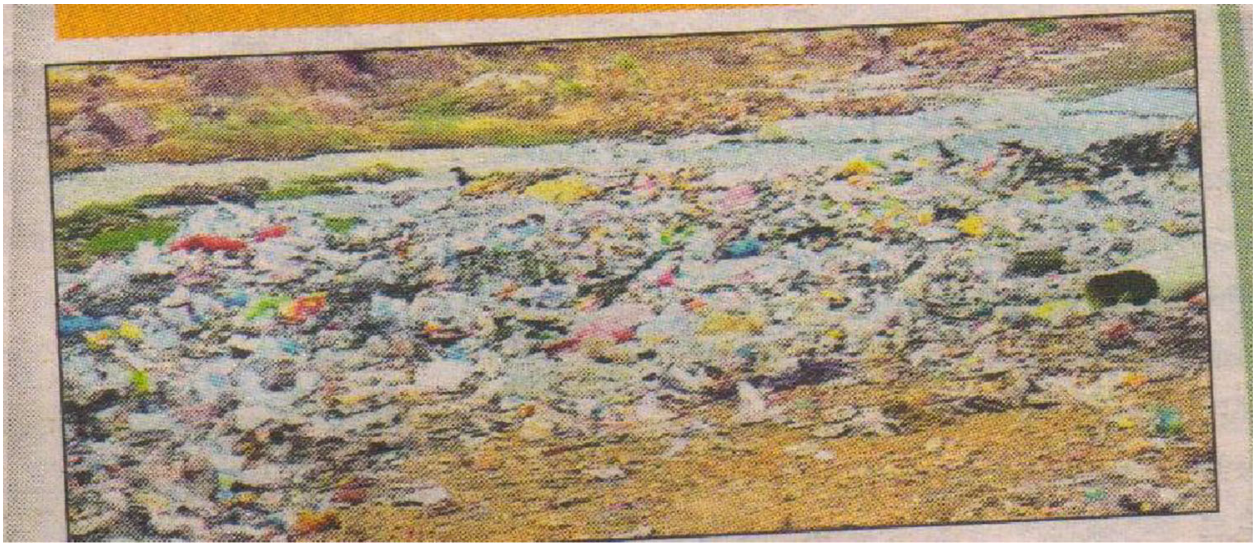

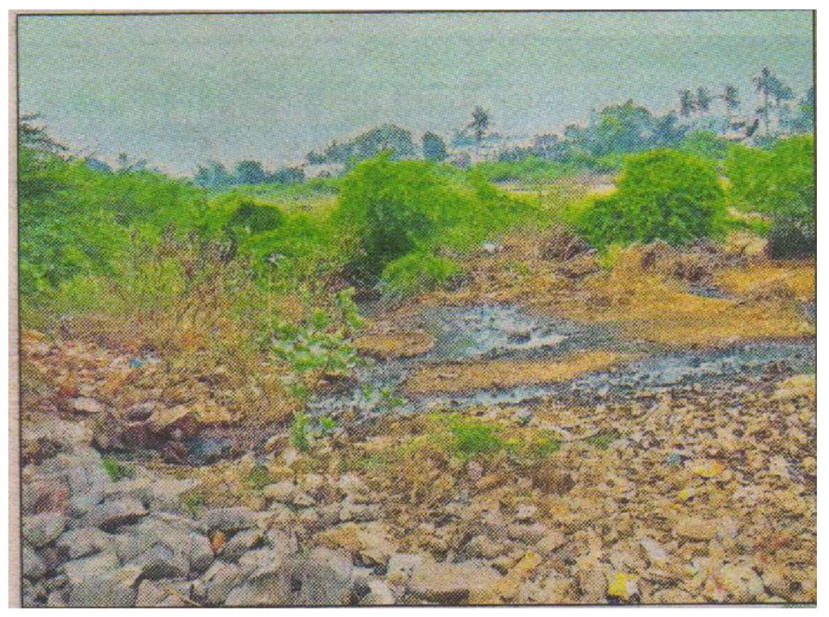

Fig. 23 Drainage fed into Champavathi River

of Andra reservoir, the concentration of nitrite in both the reservoir waters was found to be well in accordance with the standard values stipulated.

The water quality index (WQI), calculated from the parameters analyzed was found to be within the range of 23.5-38.7 for the Andra reservoir and 26.9-39.6 for Denkada anicut. From the water quality index ratings, the quality of the water of the two reservoirs was rated as "Good" for human consumption. From the correlation of irrigation water quality data, it was found that all the irrigation water quality parameters analyzed such as SAR, RSC, \% Na and magnesium hazard (Pavan Kumar 2014; Sarath Prasanth et al. 2012; Nagaraju et al. 2014) were found to be within the standard values.

In the water samples analyzed from the two reservoirs, silica was present in higher concentrations. Heavy metals such as $\mathrm{Al}, \mathrm{Zn}, \mathrm{Cd}, \mathrm{Hg}$, As, $\mathrm{Co}, \mathrm{Ni}, \mathrm{Ti}, \mathrm{Ba}$ and $\mathrm{Mn}$ were found to be below detection limits in the water samples analyzed by ICP-OES. From such data, it is inferred that the water analyzed from the two reservoirs is suitable for irrigation, and agricultural and domestic purposes.

\section{Conclusions}

From the results obtained, it was found that the water quality index and the concentration of certain parameters such as sodium, potassium, chloride and phosphate of the waters of Andra reservoir are higher than that of Denkada anicut. The water from Andra reservoir is released to reach Denkada anicut, downstream; as most of the soil in the 
riverbed is red soil and sandy loams, the variation is due to the percolation of the chemicals mentioned above through the soil on which the river flows. The same trend was observed in most of the seasons under investigation. Nitrite ion concentrations were found to be higher in the water samples of Denkada anicut due to the contamination of the water by automobile wastes and household seepage. The lower concentration levels of fluoride in the water samples of Denkada anicut indicate that the water is free from contamination by agricultural runoff. Heavy metals were found to below detection limits in the two reservoir waters. From the analysis reports, it is concluded that the water of the two reservoirs is fit for irrigation, agriculture, and industrial and domestic purposes.

Acknowledgments One of the authors is grateful to the principal and the management of M V G R College of Engineering for their support and encouragement.

Open Access This article is distributed under the terms of the Creative Commons Attribution 4.0 International License (http:// creativecommons.org/licenses/by/4.0/), which permits unrestricted use, distribution, and reproduction in any medium, provided you give appropriate credit to the original author(s) and the source, provide a link to the Creative Commons license, and indicate if changes were made.

\section{References}

Akoto O, Abankua E (2014) Evaluation of Oqabi reservoir (Ghana) water quality using factor analysis. Lakes Reserv Res Manag 19:174-182

Bhadja P et al (2013) Assessment of physico-chemical parameters and water quality index of reservoir water. IJPAES 3(3):89-95

BIS (1991) Drinking water specification. India

Chaudhary R (1941) Morphological grouping of red soil. ICAR

Chwowdary R, Rawtani P, Viswakarma M (2011) Comparative study of drinking water quality parameters of three Manmade
Reservoirs i.e., Kolar, Kaliasote and Kerwa Dam. Curr World Environ 6(1):145-149

Clesceri LS (1993) Standard methods of examination of water and waste water. APHA

Janeshwar Y et al (2012) Analysis of water quality using physicochemical parameters, satak reservoir in Khargone district MP, India. Int Res J Environ Sci 2(1):9-11

John Mohammad M et al (2015) Analysis of water quality using limological studies of Wyra reservoir Khammam district, Telangana, India. Int J Curr Microbiol App Sci 4(2):880-895

Nabila B et al (2014) An assessment of the physico-chemical parameters of Oran sebkha basin. Appl Water Sci 4:351-356

Nagaraju A et al (2014) Assessment of ground water quality for irrigation: a case study from Bandalamottu lead mining area, Guntur district, Andhra Pradesh. Appl Water Sci 4:385-396

Pandey AK, Siddiqi SZ, Rao Rama (1993) Physicochemical and biological characteristics of Husain sagar, an industrially polluted lake, Hyderabad. Proc Acad Environ Biol 2(2):161-167

Pavan Kumar GVSR (2014) Water quality status of Andra reservoir in Vizianagaram district of Andhra Pradesh, India. J Appl Chem 3(5):2095-2101

Pavan Kumar GVSR et al (2013) Assessment of Water quality status of Thatipudi reservoir of Vizianagaram district, Andhra Pradesh. INnov J Sci 1(2):20-24

Sarath Prasanth SV et al (2012) Evaluation of ground water quality and its suitability for drinking and agricultural use in the coastal stretch of Alappuzha district, Kerala, India. Appl Water Sci 2:165-175

Sharma KK et al. (2013) Assessment of fluoride in ground and surface water bodies and its seasonal variation at Bishnah Tehsil of Jammu district, J\&K: correlation with physic-chemical parameters. Int J Recent Sci Res 4(11):1736-1747

Swaranlatha S, Narsingrao A (1998) Ecological studies of Banjara Lake with reference to water pollution. J Envi Biol 19(2):179-186

Tirupathaiah M et al (2012) Analysis of water quality using physico chemical parameters in lower Maniar reservoir of Karimnagar district of Andhra Pradesh. Int J Environ Sci 3(1):172-180

Vaghela AK (2013) Assessment of physico-chemical parameters and water quality index of reservoir water. IJPAES 3(3):89-95

WHO (1993) Guidelines for drinking water quality-I, recommendations, 2nd edn. World health organization, Geneva 